\title{
Differences in Ethical Judgment between Accounting Students: An Experiment using Ethical-dilemma Movie and Ignatian Pedagogical Paradigm
}

\author{
Antonius Diksa Kuntara* \\ Universitas Sanata Dharma, Indonesia
}

\begin{abstract}
The study tries to seek evidence whether the ethical judgment of the accounting students following treatment of watching ethical-dilemma movie and make a reflection as suggested by Ignatian Pedagogical Paradigm Approach. The study is a quasi-experimental using posttest only with an experimental and control group approach. Using the respondents of senior accounting students in a university in Indonesia, we found no ethical judgment difference between students received the treatment and the control group. However, the score of the treated group was higher than the score of the control group. Under a specific limitation, this study suggests that a reflective learning method is an excellent idea to improve students' ethical judgment.
\end{abstract}

Keywords: reflection, accounting students, ethical judgment, Ignatian pedagogical paradigm, ethical dilemma movie.

\section{Introduction}

At the beginning of the new millennium, we were shocked with scandals involving public accounting firms in the US, leading to the collapse of companies such as Enron and Worldcom. The phenomenon have been predicted previously mentioning that accounting professionalism had lost its significance in the 1980s and 1990 (Wyatt, 2004). The cause of the problem was thought to be the employment of university graduates who were more commercially driven than professionally accounting driven to work in public accounting companies. The abovementioned workers were stated to be loose and not conservative in keeping the accounting principle.

Building accounting professionalism needs efforts and time. To be a professional accountant, one should attend certain formal accounting education. The four years of undergraduate study in accounting is substantial in shaping student's accounting professionalism. Besides learning how to prepare a financial report to produce valuable information, students also learn values that build their integrity. This period lays important fundamentals to build accounting professionalism and shapes students' behavior (Velayutham and Perera, 2008).

A critical aspect of accounting professionalism is the ability to make ethical judgments. A good ethical judgment will lead to an ethical decision. To be professional accountants, students should learn this judgment since they were in the university. Scholars have highlighted the importance of this ethics education for accounting students (Armstrong et al., 2003; Blanthorne et al., 2007; Gaa and Thorne, 2004; Haas, 2005; McManus et al., 2012; Mintz, 2007; Waddock, 2005). Since 2006 International Accounting Education Standards Board (IAESB), a standard-setting board of the International Federation of Accountants (IFAC) with the paper entitled Approaches to the Development and

\footnotetext{
${ }^{*}$ Corresponding author. Email: diksa.kuntara@gmail.com.
} 
Maintenance of Professional Values, Ethics, and Attitudes in Accounting Education Programs had pinpointed the importance of ethics education for accounting students (Cooper, 2001). Students should learn ethics, and universities should employ ethics or business ethics in their curriculum.

Universities try to include ethics education in their curriculum. Some faculties integrate ethics in individual courses and even advocate separate standalone units for this subject (Mc Avoy et al., 2012; McManus et al., 2012). Recently, Jesuits universities try to embed this ethics subject through reflective learning, usually called a Ignatian Pedagogical Paradigm (Hise and Massey, 2010).

Present studies shows that students taking a business ethics subject tend to show significant improvements on their ethical weighing, their recognition of ethical issues and their performance in ethical decision-making ( $\mathrm{Wu}, 2003)$. However, there is another study suggesting that there is no relationship between education level (sophomore, junior, senior, and graduate) and personal ethical philosophy (Zeigenfuss, 1999). The study suggested that integrating ethics throughout a curriculum have little or no effect on a student's ethical philosophy.

This study wants to evaluate the effectiveness of a specific learning method, the Ignatian Pedagogical Paradigm, and the use of an ethical-dilemma movie in enhancing the ethical judgment of the accounting students. It tries to seek evidence whether there is a difference in term of student's ethical judgment between the group of accounting students which was given the treatment with the other group which was not given the treatment (the control group). The study was conducted at the accounting department of a private university in Indonesia.

\section{Conceptual background Ethical decision making}

The study of ethical decision making can be traced back to the work of Rest (1986) who introduced a four-step model of ethical decision making. It involves recognizing the moral issue, making a moral judgment, resolving to place moral concerns ahead of other concerns and acting on moral concerns. Further study by (Craft, 2013) categorizes works of literature into four dependent variables based on Rest (1986) model: awareness, intent, judgment, and behavior. Some factors have been identified as affecting ethical decision making. They include gender, age, personality, education/ employment/ experience, cultural values, philosophy/value orientation, and situation (Craft, 2013).

Education is an important aspect which can affect ethical decision making. Cagle and Baucus (2006)stated that after studying ethic scandals students' decision-making change. Other study conducted by $\mathrm{Wu}$ (2003) shows that by taking business ethics subject, students' ethical weighing, recognition of ethical issues and their performance in ethical decision-making are improved. Method of teaching, as well as material being learned, can also develop a student's ethical decision making. An observation towards third-year accounting students following auditing course by O'Leary and Stewart (2013) found that all modes of teaching had an effect. They argued that the effect was stronger if the student's learning style fit with the teaching methodology. About the likelihood to whistle-blow, Liyanarachchi and Newdick (2009) concluded that accounting education could improve ethical awareness. The use of the web-based method was sufficient to improve students' likelihood to whistleblow (McManus et al., 2012).

Several approaches and methods of teaching have been explored and relatively new course design is proposed in the pursuance of ethical decision making of the student. McManus et al. (2012) explored the use of web-based teaching module and its effect on student's propensity to whistle-blow. Haywood et al. (2004)observed the use of games as a strategy to enhance student's ethical awareness.

Following the proposition of O'Leary and Stewart (2013)which states that modes of teaching has an effect towards student's ethical decision making, a relatively new design of accounting ethic course was proposed as have also been done by Hise and Massey (2010) by using a reflective pedagogy namely Ignatian Pedagogical Paradigm (IPP). The pedagogy puts reflection in its learning cycle and is an essential step before making the actions (see also Mc Avoy et al. (2012)). However, up to now, there is no study evaluating the effectiveness of this approach concerning its ability to improve students' ethical decision making. This motivates the study.

\section{The reflective pedagogy: IPP}

Ignatian Pedagogical Paradigm (IPP) was originally used by colleges of Jesuits. It was initiated by the experience of St. Ignatius Loyola (1491-1556), the founder of the Societas of Jesus (the Jesuits) in 
guiding his friends both in doing the Spiritual Exercise and studying masters level at Paris University (Coghlan and Coghlan, 2005). The pedagogy then documented in Ratio Studiorum (Latin for "Plan of Studies") in 1599 (Hise and Massey, 2010). In 1980, Pater Pedro Arupe, the General of Societas Jesu, form a commission to reformulate the identity of Jesuit Education. A document titled "The Characteristic of Jesuit Education" was published in 1986. Three years afterwards, there was an appeal from all over the world for practical guidance for applying it in daily activity at school. In 1993 after conducting several researches, an International Commission for Education published "Ignatian Pedagogy: A Practical Approach." That document now serves as guidance for implementing Ignatian Pedagogy in high schools as well as in universities.

Ignatian Pedagogy is implemented following a cycle consisting of 5 steps: context, experience, reflection, action, and evaluation (see figure 2.1). Context is a "personal care and concern for the individual, which is a hallmark of Jesuit education." It requires that the teacher become as conversant as possible with the life experience or the learner (JSEA, 1993). Learning context could have some aspects such as physic, sociology, politics, culture, and spiritual. Experience is simply any activity in which student will have addition to a cognitive grasp of the matter being considered (JSEA, 1993). Through the experience step, the student will be engaged with activities involving mind, heart, and willingness towards the subjects being explored. The step will be followed by a reflection in which student reconsidering the substance of the subject being explored. In reflection, students utilize the power of memorizing, understanding, imagination and feelings to catch up the meaning and essential values of what is being experienced. In Ignatian Pedagogy, reflection is a process to result in a meaning in a human experience. A good reflection will encourage people to do action(s), which is the last step in the cycle. The term action is pointing an inner growing based on experience that has been reflected. Action consisting of two steps: firstly, to develop an internal choice that will appear in their priority of life and secondly to concrete the choice trough real action. The meaning, attitude, and values that students follow will drive them to perform action consistent with their new conviction. If it is positive, the student will intensify the attitude and action, while if it is negative, they will impede or alter it.

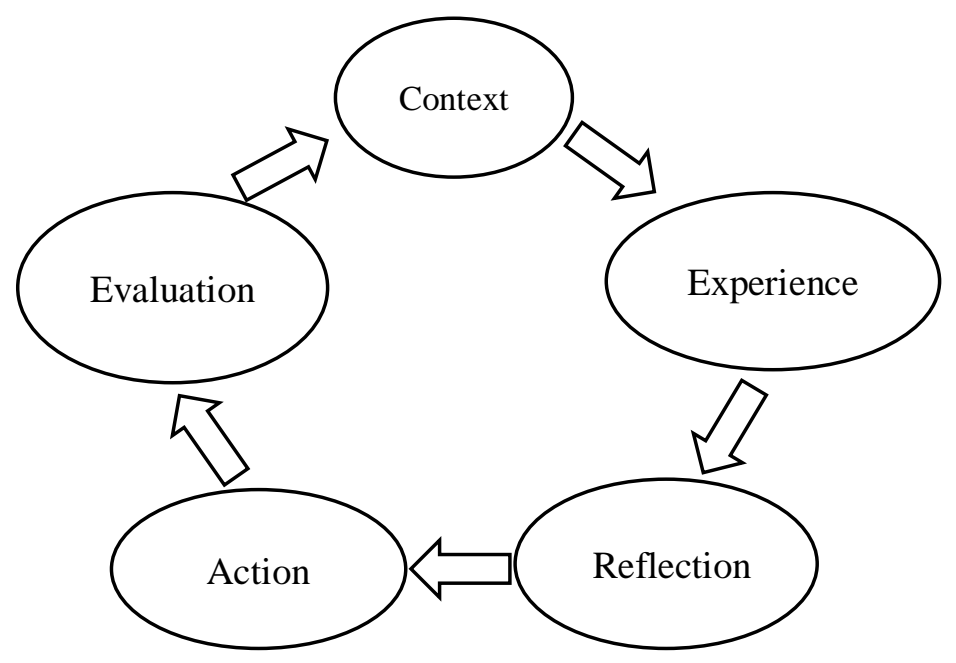

Figure 1. Ignatian Pedagogical Paradigm Cycle

An ideal learning process should start with experience (Moon 2004, p.104). The pedagogy is combining experiential and reflective learning. The approach can be categorized as a constructivist view of learning which believes that the learner gives the meaning by himself about the world or subject being learned.

Learning development is described as a strong but flexible network between ideas and feelings rather than the accumulation of knowledge (Moon, 2004). The process is not just the accumulation of material being learned, but more about the process of change in a person's conception (Bowden and Marton, 1998). Learning also involves emotions (feelings). (Goleman, 2005) Gave rise to "emotional intelligent" (EQ), and studies have been conducted to link this concept with learning abilities (Moon, 2004). Supelli 
(2015) mentioned the importance of reflection to be included in the learning process of the student. This seems to be able to change their behavior to a more positive direction. With reflection, they act not only based on the theory they have learnt, nor just by their intention, but will also involve their feelings, especially their empathy to others.

Study about the reflective approach of learning and the performance of the student has been conducted i.e., by Sriyanto (2015) which examined the application of reflective pedagogy in teaching mathematics in high school. With a quasi-experimental design, they found that the critical thinking skills and student's math anxiety, the reflective pedagogical approach is better than the conventional method. While in terms of student achievement, this pedagogy is not more effective than conventional pedagogy. This is consistent with the research of Balci and Demirbas (2012), which examines the application of a reflective approach to teaching science in elementary schools. They found that the reflective approach had no effect on students' academic achievement but allows students to retain their value in terms of scientific attitude.

\section{Research Method}

This research was quasi-experimental using "posttest only with experimental and control group" design (Sekaran, 2003). The design is free from the testing effect since there is no pretest during the study (Sekaran, 2003). This study was observing two groups of senior accounting students $\left(5^{\text {th }}\right.$ semester) and treatment was given to the experiment group (see Table 1). The ethical judgments of the students were measured by providing posttest. The study was conducted in July until December 2015 in the university where the author works.

Table 1. The experimental design

\begin{tabular}{ccccc}
\hline Group $\mathrm{Nr}$ & Group & Pretest & Treatment & Posttest \\
\hline 1 & Experiment & & $\mathrm{X}$ & $\mathrm{O}_{1}$ \\
2 & Control & & & $\mathrm{O}_{2}$ \\
\hline
\end{tabular}

The three main stages (cycle) of the IPP: experience, reflection, and action were used in the experimental process. Experience is the use of the movie media; reflection is a written expression of the student's feeling about the movie while the action is the answers of the students to the questions about the particular case being used. The IPP cycle followed by the students in the experiment group can be seen in Table 2 . The answers of the students reflect their ethical judgment.

Table 2. The Ignatian Pedagogical Paradigm Cycle in this study

\begin{tabular}{|c|c|c|}
\hline $\mathrm{Nr}$ & IPP Cycle & Description \\
\hline 1 & Context & $\begin{array}{l}\text { Conduct a survey towards students' understanding on the ethical } \\
\text { judgment. }\end{array}$ \\
\hline 2 & Experience & $\begin{array}{l}\text { See an ethical dilemma movie in the business world, "The Company } \\
\text { Men" }\end{array}$ \\
\hline 3 & Reflection & $\begin{array}{l}\text { Students were asked to write a reflection paper about their experience } \\
\text { and feeling about the movie they had watched }\end{array}$ \\
\hline 4 & Action & $\begin{array}{l}\text { (a) In the reflection paper, students wrote their proposed action } \\
\text { following their reflection } \\
\text { (b) The student read the case and decide their judgment by answering } \\
\text { the questions on the questionnaire }\end{array}$ \\
\hline 5 & Evaluation & $\begin{array}{l}\text { The students were evaluated by the lecturer about the process of the } \\
\text { study }\end{array}$ \\
\hline
\end{tabular}

The data of this research was the score of the students' ethical judgment in answering several questions towards a case. Questions in the questionnaire were close-ended questions with alternative answers from Strongly Disagree to Strongly Agree with the Likert scale ranging from 1-7. The questionnaire was developed from ethics cases in the accounting profession developed by the Consultative Committee of Accountancy Bodies (CCAB), (2011). 
The success of the experiment was assessed based on the treatment effect (E). In this design, the treatment effect was measured as follows:

$$
\mathrm{E}=\left(\mathrm{O}_{1}-\mathrm{O}_{2}\right)
$$

The causal relationship between the treatment and the student's ethical judgment will be proven if the treatment effect is positive. To identify the significance of the difference in scores between groups, Levine's test was used.

The treatment for this research was the experience given to the student by letting them see an ethical dilemma movie. The selected movie is "Company Men" which tells about a young worker who raises a family but affected by layoffs in the company where he worked.

\section{Result}

Before the actual treatment of experiments was conducted, a pilot test had been administered. The pilot test was conducted to 10 students who were not the participants of the study. The treatment of seeing the movie titled "The Company Men" was given and the students were asked to do the reflection. The questionnaire was then administered. After that, the participants were asked to provide input for improvement. The results of the pilot test showed that the manipulation check questions were well understood and all items in the questionnaire were valid and reliable. The manipulation check and the questionnaires which had been revised was used for the actual experiment.

As many as 37 students followed the treatment and were in the experiment group (Group 1), while the other 22 students were in the control group (Group 2) (See Table 5). The validity of the questionnaire was tested using Pearson-correlation and can be seen in Table 3. From the nine questions in the questionnaire, all items were valid. The questionnaire was also tested for its reliability using Cronbach's Alpha and resulted in 0.642. Since it was more than 0.6 , the questionnaire was considered as reliable.

Table 3 The result of validity test

\begin{tabular}{lll}
\hline Question & r-count & r-table \\
\hline Q1 & $0.460^{* *}$ & 0.1381 \\
Q2 & $0.500^{* *}$ & 0.1381 \\
Q3 & $0.458^{* *}$ & 0.1381 \\
Q4 & $0.542^{* *}$ & 0.1381 \\
Q5 & $0.474^{* *}$ & 0.1381 \\
Q6 & $0.608^{* *}$ & 0.1381 \\
Q7 & $0.342^{* *}$ & 0.1381 \\
Q8 & $0.553^{* *}$ & 0.1381 \\
Q9 & $0.600^{* *}$ & 0.1381 \\
\hline **. Correlation is significant at the 0.01 level (2-tailed). \\
*. Correlation is significant at the 0.05 level (2-tailed).
\end{tabular}

In order the data can be processed, the student must pass two types of manipulation checks. The first manipulation check was the question about the film which consists of 7 close-ended questions related to the substance of the film. The second manipulation check was another 7 close-ended questions about the comprehension of the fundamentals of financial and capital markets discussed in the case. The student should be able to answer correctly at least 4 questions. Specifically for the treatment group, the student should write a reflection of at least 1 paragraph (at least 5 sentences). If the written reflection contained less than the required sentences, the data was excluded.

Table 4 The result of observation and treatment effect

\begin{tabular}{llll}
\hline Observation & Mean & Std Dev & Group \\
\hline O1 & 48.97 & 5.885 & Experiment \\
O2 & 46.55 & 4.935 & Control \\
\hline
\end{tabular}

Treatment Effect $(\mathrm{E})=48.97-46.55=2.42$

The results of the observation and assessment of treatment effect can be seen in Table 4. From the table, it appears that the experimental treatment yielded positive results. However, once tested using 
Levine's test (see Table 5), it showed that there was no real difference between the two groups. It can thus be concluded that the treatment did not produce the effect as expected.

Table 5. Result of Levine's test (SPSS output)

\begin{tabular}{cccccc}
\multicolumn{6}{c}{ Group Test } \\
\hline & Group & $\mathrm{N}$ & Mean & Std. Deviation & Std. Error Mean \\
\hline Score & 1 & 37 & 48.97 & 5.885 & .968 \\
& 2 & 22 & 46.55 & 4.935 & 1.052 \\
\hline
\end{tabular}

Independent Samples Test

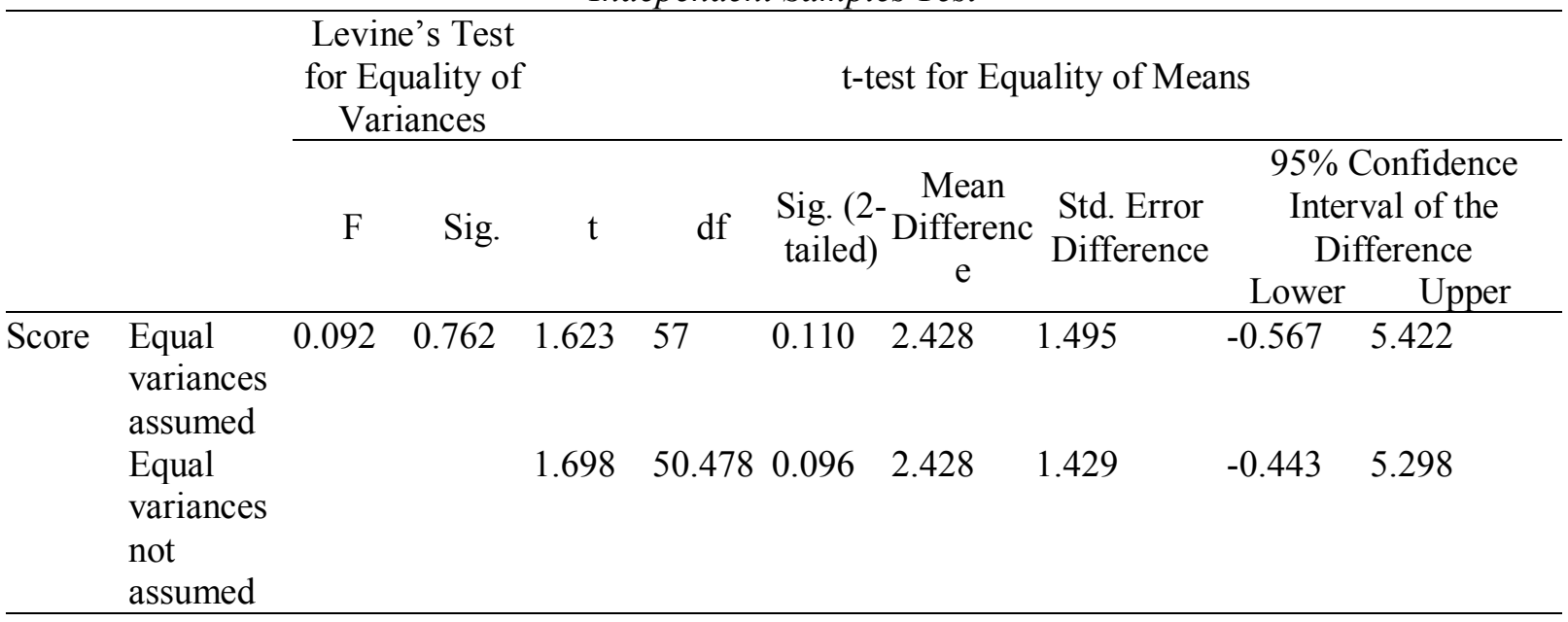

\section{Discussion and Conclusion}

From the analysis it can be concluded that there is no difference in terms of ethical judgment between the accounting students who receive treatment with the other groups who did not receive the treatment (the control group). In general, the result is consistent with the study of Sriyanto (2015) and Balci and Demirbas (2012).

There are several possible causes for this to happen. First, there is a high score of student's attitudes. From the observation, the average score of student attitudes in the control group had been in the range of 4 (out of 7). This high score indicates that the respondents have already had a certain position towards the statements in the questionnaire. With this condition, either with or without the treatment, the respondents' attitudes will not differ significantly.

Second, a treatment in the form of the movie may have a less immediate effect for a change of attitude of the student. A direct link between the movie and the question may not be captured well by the students. The students probably could not connect the value reflected in the story of the movie with the statements in the questionnaire.

Thirdly, the questions in the questionnaire may need to be improved. Although they had passed the test of validity and reliability, they need to fit the construct validity test. There is a possibility that the questions in the questionnaire were interpreted ambiguously by the respondent. Questions that lead to one answer e.g., the use of the word "should" may cause respondents to agree with the statement.

The study has a limitation in exploring the reflection of the students. Further study may consider this ability and explore whether good reflection can lead to better judgments. This study is just assuming that students who make good reflections on the experience they have just had by seeing the movie can internalize the values inferred in the story. Apart from the limitation of this study, the result gives an indication that the reflective pedagogical approach can be a good idea to improve the ethical judgment of the accounting student. Suggestions proposed above hopefully will improve future research so that the result will be sturdier.

\section{References}

Armstrong, M.B., J.E.Ketz and D.Owsen. (2003), "Ethics education in accounting: moving toward ethical motivation and ethical behavior", Journal of Accounting Education, Vol. 21, pp. 1-16. 
Balci, F. and Demirbas, M. (2012), "The Effect of the Directly Reflective Approach to Teaching the Nature of Science in Science and Technology Education on Academic Achievement and Scientific Attitude", International Journal of Academic Research in Business and Social Sciences, Vol. 2 No. 9.

Blanthorne, C., Kovar, S. and Fisher, D. (2007), “Accounting Educators' Opinions About Ethics in the Curriculum: An Extensive View”, Issues in Accounting Education, Vol. 22 No. 3, pp. 355-39o.

Bowden, J. and Marton, F. (1998), The University of Learning: Beyond Quality and Competence in Higher Education, Kogan Page, London.

Cagle, J.A.B. and Baucus, M.S. (2006), "Case studies of ethics scandals: Effects on ethical perceptions of finance students", Journal of Business Ethics, Vol. 64, pp. 213-229.

Coghlan, D. and Coghlan, D. (2005), "transformational social science", available at:https://doi.org/10.1177/1476750305049967.

Consultative Committee of Accountancy Bodies (CCAB). (2011), "Ethical Dilemmas Case Studies: Professional Accountants in Public Practice", available at: www.ccab.org.uk.

Cooper, D. (2001), Improving Safety Culture: A Practical Guide, Applied Behavior Sciences, Hill.

Craft, J.L. (2013), “A Review of the Empirical Ethical Decision-Making Literature: 2004-2011”, Journal of Business Ethics, Vol. 90, pp. 221-259.

Gaa, J.C. and Thorne, L. (2004), "An introduction to the special issue on professionalism and ethics in accounting education", Issues in Accounting Education, Vol. 19, pp. 1-6.

Goleman, D. (2005), Emotional Intelligence: Why It Can Matter More Than IQ.

Haas, A. (2005), "Now is the Time for Ethics in Education", The CPA Journal, Vol. 75 No. 6, pp. 66-68.

Haywood, M.E., McMullen, D.A. and Wygal, D.E. (2004), "Using games to enhance student understanding of professional and ethics responsibilities”, Issues in Accounting Education, Vol. 19, pp. 85-99.

Hise, J. van and Massey, D.W. (2010), "Applying the Ignatian Pedagogical Paradigm to the Creation of an Accounting Ethics Course”, Journal of Business Ethics, Vol. 96, pp. 453-465.

Jesuit Secondary Education Associatin JSEA. (1993), Ignatian Pedagogy: A Practical Approach.

Liyanarachchi, G. and Newdick, C. (2009), "The impact of moral reasoning on whistle-blowing: New Zealand evidence", Journal of Business Ethics, Vol. 89, pp. 37-57.

Mc Avoy, M., Crowe, T., Lotz, R. and Truka, B. (2012), "The Influence of the Ignatian Pedagogical Paradigm on Instructors Integrating It into Undergraduate Courses in the College of Professional Studies at Marquette University", Jesuit Higher Education, Vol. 1 No. 2, pp. 82-105.

McManus, L., Subramaniam, N. and James, W. (2012), "A Comparative Study of the Effect of Web-Based Versus InClass Textbook Ethics Instruction on Accounting Students' Propensity to Whistle-Blow”, Journal of Education for Business, Vol. 87 No. 6, pp. 333-342.

Mintz, S. (2007), "Loeb's Contribution to Accounting Ethics Education and Research", Research on Professional Responsibility and Ethics in Accounting, Vol. 11, pp. 31-46.

Moon, J.A. (2004), A Handbook of Reflective and Experiential Learning: Theory and Practice, Routledge Falmer (Taylor \& Francis Group), London and New York.

O'Leary, C. and Stewart, J. (2013), "The interaction of learning styles and teaching methodologies in accounting ethical instruction", Journal of Business Ethics, Vol. 113 No. 1, pp. 225-241.

Rest, J.R. (1986), Moral Development: Advances in Research and Theory, Praeger, New York.

Sekaran, U. (2003), Research Methods for Business, A Skill Building Approach, John Wiley \& Sons, Inc, New York.

Sriyanto, H.J. and J. (2015), Keefektifan Pendekatan Pedagogi Reflektif Ditinjau Dari Prestasi Belajar, Kemampuan Berpikir Kritis Dan Kecemasan Matematika. (The Effectiveness of Reflective Pedagogical Approach in Terms of Learning Achievement, Critical Thinking Ability and Math Anxiet, Yogyakarta.

Supelli, K. (2015), "Speech on National Seminar on Education held in Sanata Dharma University", Yogyakarta Indonesia.

Velayutham, S. and Perera, H. (2008), "The role of professional accounting programmes: towards a reflective practicum", International Journal of Management Education, Vol. 7 No. 1, pp. 29 - 40.

Waddock, S. (2005), “Accounting Professionalism - They Just Don't Get It! Accounting Horizons”, Issues in Accounting Education, Vol. 20 No. 2, pp. 145-150.

$\mathrm{Wu}, \mathrm{C.F}$. (2003), "A study of the adjustment of ethical recognition and ethical decision- making of managers-to-be across the Taiwan Strait before and after receiving a business ethics education”, Journal of Business Ethics, Vol. 45, pp. 291-307.

Wyatt, A.R. (2004), “Accounting Professionalism - They Just Don't Get It! Accounting Horizons”, AAA Anual Meeting, Honolulu, Hawaii.

Zeigenfuss, D.E. (1999), "Differences in personal ethical philosophy among accounting students and between accounting students and practitioners", Southern Business Review, Vol. 25, pp. 1-9. 